\title{
ANALISIS KEMAMPUAN BERPIKIR KREATIF PADA MATERI CAHAYA SISWA KELAS VIII SMP XAVERIUS KOTA LUBUKLINGGAU
}

\author{
Wahyu Arini ${ }^{1}$, Asista Asmila ${ }^{2}$, \\ STKIP-PGRI Lubuklinggau ${ }^{1,2}$ \\ wahyuarini02@gmail.com ${ }^{1}$
}

\author{
Submit, 09-11-2017 Accepted, 29-12-2017 Publish, 29-12-2017
}

\begin{abstract}
; the purpose of this research is to describe students 'creative thinking ability in light matter, to know the students' creative thinking ability in light matter when viewed from cognitive observation and affective observation, to know the difficulties experienced by students in achieving the indicators of creative thinking ability and determination solution to overcome student difficulties in achieving the indicators of creative thinking ability of class VIII.D SMP Xaverius Kota Lubuklinggau. The type of this research is descriptive qualitative, with case study research type. The subject of this research is all students of class VIII SMP Xaverius Kota Lubuklinggau. Data completion technique in this research is using technique triangulation that is cognitive observation technique, affective observation, and interview. Data analysis technique is descriptive qualitative analysis. The result showed that students' thinking ability of class VIII.D junior Xaverius Kota Lubuklinggau still less creative (36,68\%) based on result of cognitive observation which was completed with interview result and creative enough category $(57,74 \%)$ result of affective observation. the recommendations that can be submitted in this research is the teacher will give equal opportunity to all students to be able to develop the ability of creative thinking in the learning process.
\end{abstract}

Keywords: Analysis, Creative Thinking, Light.

\begin{abstract}
Abstrak :tujuan penelitian ini adalah untuk mendeskripsikan kemampuan berpikir kreatif siswa pada materi cahaya, mengetahui kemampuan berpikir kreatif siswa pada materi cahaya jika ditinjau dari observasi kognitif dan observasi afektif, mengetahui kesulitan-kesulitan yang dialami oleh siswa dalam mencapai indikator-indikator kemampuan berpikir kreatif, dan menentukan solusi untuk mengatasi kesulitan siswa dalam mencapai indikator-indikator kemampuan berpikir kreatif dikelas VIII.D SMP Xaverius Kota Lubuklinggau. Jenis penelitian ini adalah deskriptif kualitatif, dengan tipe penelitian studi kasus. Subjek penelitian ini adalah seluruh siswa kelas VIII SMP Xaverius Kota Lubuklinggau. Teknik pengumpulan data dalam penelitian ini adalah menggunakan triangulasi teknik yaitu teknik observasi kognitif, observasi afektif, dan wawancara. Teknik analisis data adalah analisis deskriptif kualitatif. Dari hasil penelitian menunjukkan bahwa kemampuan berpikir kreatif siswa pada materi cahaya kelas VIII.D SMP Xaverius Kota Lubuklinggau masih kurang kreatif (36,68\%) berdasarkan hasil observasi kognitif yang dilengkapi dengan hasil wawancara dan kategori cukup kreatif (57,74\%) berdasarkan hasil observasi afektif. rekomendasi yang dapat diajukan dalam penelitian ini adalah guru hendaknya memberikan kesempatan yang sama pada semua siswa untuk dapat mengembangkan kemampuan berpikir kreatifnya dalam proses pembelajaran.
\end{abstract}

Kata Kunci: Analisis, Berpikir Kreatif, Cahaya.

\section{PENDAHULUAN}

Seiring dengan pembaharuan sistem pendidikan, pemerintah telah menetapkan fungsi dan tujuan pendidikan nasional salah satunya yaitu berfungsi mengembangkan kemampuan serta peradaban bangsa yang kreatif, jadi untuk mengembangkan potensi peserta didik agar menjadi manusia yang kreatif tidak akan berjalan dengan baik jika peran guru tidak ada dalam mencapai 
tujuan tersebut. Kompri (2015) menyatakan bahwa guru yang berkualitas merupakan ujung tombak pencapaian tujuan pendidikan nasional salah satunya mewujudkan insan Indonesia yang kreatif. Berpikir kreatif dalam hal ini merupakan pola pikir siswa yang dapat menghasilkan banyak ide bervarisai yang sebelumnya tidak ada.

Fisika mempunyai peranan penting dalam berbagai disiplin ilmu, oleh karena itu penting untuk mengintegrasikan kemampuan berpikir kreatif dalam mata pelajaran IPA Fisika, karena kemajuan sebuah zaman dan kualitas beradaban tidak lagi di sandarkan pada kekuatan sumber daya alam secara utuh melainkan sangat diperlukan manusia-manusia yang mampu berpikir kreatif. Salah satu kemampuan berpikir yang sering diabaikan dalam pendidikan formal adalah kemampuan berpikir kreatif dan belum ditangani secara sungguh-sungguh oleh para guru di sekolah, dapat dikatakan pengembangan kreativitas ditelantarkan dalam pendidikan formal, padahal amat bermakna bagi pengembangan potensi anak secara utuh, hal ini juga diungkapkan oleh Munandar (2009) menyatakan bahwa berpikir kreatif kurang dirangsang, sehingga anak tidak terbiasa berpikir bermacam-macam arah. Untuk itulah, kreativitas atau berpikir kreatif perlu dilatih, dipupuk, dikembangkan dan ditingkatkan, mulai dari pendidikan pra sekolah sampai di perguruan tinggi. Oleh karena itu perlu adanya suatu pembelajaran yang mampu menimbulkan keterampilan berpikir kreatif.

Dalam proses pembelajaran di sekolah Guru memberikan soal ulangan yang sama dari contoh soal yang pernah dibahas dan pada saat peneliti mengobservasi buku latihan IPA siswa kelas VIII sebanyak sepuluh orang ternyata soal-soal tersebut sama dengan soal-soal yang pernah dibahas di buku catatan, sehingga karakter siswa yang muncul hanya mempersiapkan diri untuk menghapal dan belajar apa yang sudah dijelaskan oleh guru saja. Siswa cenderung malas mengerjakan soal yang menurut mereka sulit dan sedikit berbeda dengan contoh soal untuk dipecahkan karena siswa tidak terbiasa dilatih dan diarahkan untuk berpikir kreatif. Oleh karena itu sebagai seorang guru yang beperan penting dalam dunia pendidikan perlu memupukkan bahwa berpikir kreatif itu penting dimulai dari hal yang terkecil hingga untuk menghadapi masalah-masalah, selanjutnya menurut (Munandar,2009) pengembangan kreativitas secara eksplisit dinyatakan pada setiap tahapan perkembangan anak, mulai dari pendidikan pra-sekolah sampai di perguruan tinggi. Berpikir kreatif kurang dirangsang, sehingga anak tak terbiasa berpikir bermacam-macam arah. Untuk itulah, kreativitas atau berpikir kreatif perlu dilatih,

Berdasarkan penjelasan yang diuraikan di atas dan beberapa permasalahan di atas,rumusan masalah dalam penelitian yaitu (1) Bagaimanakah kemampuan berpikir kreatif siswa kelas VIII SMP Xaverius Kota Lubuklinggau jika ditinjau dari hasil observasi kognitif dan afektif(2) Apa saja kendala yang dialami oleh siswa kelas VIII SMP Xaverius Kota Lubuklinggau dalam mencapai indikator-indikator kemampuan berpikir kreatif(3) Bagaimanakah solusi yang digunakan untuk mengatasi kendala siswa dalam mencapai indikator-indikator kemampuan berpikir kreatif di kelas VIII SMP Xaverius Kota Lubuklinggau tersebut.

Berdasarkan rumusan masalah yang telah di kemukakan di atas, maka tujuan yang ingin dicapai dalam penelitian ini adalah yaitu (1) Mengetahui kemampuan berpikir kreatif siswa kelas VIII SMP Xaverius Kota Lubuklinggau jika ditinjau dari hasil 
observasi kognitif dan afektif, (2) Mengetahui kendala yang dialami oleh siswa kelas VIII SMP Xaverius Kota Lubuklinggau dalam mencapai indikator-indikator kemampuan berpikir kreatif, (3)Menentukan solusi yang digunakan untuk mengatasi kendala siswa dalam mencapai indikatorindikator kemampuan berpikir kreatif di kelas VIII SMP Xaverius Kota Lubuklinggau. Kemudian, dengan adanya penelitian ini manfaat yang di harapkan adalah (1) bagi siswa, sebagai motivasi untuk bertindak bebas dalam memecahkan masalah tanpa harus terpaku pada teks book, menjadi motivasi dalam meningkatkan kemampuan berpikir kreatif dan melatih kemampuan berpikir kreatif dalam menghadapi berbagai masalah dan tantangan zaman, (2) bagi guru, sebagai motivasi untuk menciptakan suasana belajar yang menarik agar dapat meningkatkan kemampuan berpikir kreatif peserta didik,sebagai motivasi untuk lebih kreatif dalam membuat tes berdasarkan tes kemampuan berpikir kreatif sehingga guru respek terhadap gagasan yang kreatif dan tidak melumpuhkan potensi kreatif siswa, sebagai referensi tentang teknik-teknik untuk mengembangkan kreativitas siswa sehingga dapat terwujud potensi kreativitasnya.

\section{LANDASAN TEORI}

\section{Pengertian Analisis}

Banyak ahli yang merumuskan pengertian analisis yaitu Menurut Budiono (2005) menjelaskan analisis merupakan "penguraian suatu pokok atau berbagai bagiannya dan penelaahan bagian itu sendiri serta hubungan antar bagian untuk memperoleh pengertian yang tepat dan pemahaman arti keseluruhan". Sedangkan pendapat Anderson dan Krathwohl (2010) menjelaskan analisis dalam bentuk kata kerja sebagai berikut.Menganalisis melibatkan proses memecah-mecahkan materi jadi bagian-bagian kecil dan menentukan bagaimana hubungan antar bagian dan antar setiap bagian dan struktur keseluruhannya, menganalisis yaitu penentuan potongan-potongan informasi yang relevan atau penting (membedakan), menentukan cara-cara untuk menata potongan-potongan informasi tersebut (mengorganisasikan), dan menentukan tujuan dibalik informasi itu (mengatribusikan).

Dari kedua pendapat di atas, dapat disimpulkan analisis merupakan suatu proses yang diawali dari menduga kebenarannya kemudian menyelidiki, menguraikan apa yang menjadi pokok permasalahan sehingga dapat dijabarkan ke bagian-bagian yang lebih kecil setelah adanya tindakan pengkajian yang tepat untuk menentukan tujuan.

\section{Kemampuan Berpikir}

Dengan dimilikinya kemampuan berpikir yang baikseseorang akanmemiliki modal untuk bisa memecahkan masalah yang terjadi dalam kehidupannya. Sejatinya semua insan memiliki potensi untuk berpikir, namun yang membedakan satu dengan yang lain ialah karakter atau kerangka berpikirnya. Dalam kamus Oxford Advenced Learner's Dictionary (dalam Sudarma, 2013) thinking salah satunya diartikan "ideas or opinions about something". Pemikiran itu adalah ide atau opini. Dapat dikatakan orang yang berpikir itu ialah orang yang memiliki ide atau opini. Menurut Slameto (2010) Setiap orang dapat berpikir dan memecahkan masalah tetapi jelas ada perbedaan yang luas dalam kecakapan bagaimana orang tersebut memecahkannya.

Berdasarkan uraian di atas karena banyaknya variasi dari berpikir maka dalam penelitian ini peneliti hanya terbatas pada kemampuan berpikir kreatif, sehingga dapat disimpulkan kemampuan berpikir adalah kesadaran 
yang hadir dalam diri seseorang yang tidak dapat diamati secara langsung sehingga seseorang bisa beropini dan berpendapat dalam memecahkan masalah.

\section{Kemampuan Berpikir Kreatif}

Kreativitas berasal dari kata to createartinya membuat dan mencipta. Menurut Sudarma (2013) "kreativitas adalah kecerdasan yang berkembang dalam diri individu, dalam bentuk sikap, kebiasaan, dan tindakan dalam melahirkan sesuatu yang baru dan orisinil untuk memecahkan masalah". Munandar (2004) menyatakan bahwa "berpikir divergen (juga disebut berpikir kreatif) ialah memberikan macammacam kemungkinan jawaban berdasarkan informasi yang diberikan dengan penekanan pada keragaman jumlah dan kesesuaian".

Berdasarkan beberapa pendapat ahli di atas, dapat disimpulkan bahwa kemampuan berpikir kreatif adalah kemampuan yang muncul karena adanya potensi sehingga menimbulkan banyak kreativitas untuk menciptakan sesuatu yang baru dan unik dengan bantuan sesuatu yang sudah ada sebelumnya. Sedangkan kemampuan berpikir kreatif Fisika adalah kemampuan untuk menghasilkan jawaban yang bervariasi dan bermacam-macam arah bersifat baru terhadap masalah-masalah Fisika.

\section{Analisis Kemampuan Berpikir Kreatif Fisika}

Analisis kemampuan berpikir kreatif Fisika adalah sesuatu kegiatan dan proses untuk mengkaji permasalahan berupa soal atau pertanyaan yang berhubungan dengan cara membedakan, menata atau mengorganisasikan, kemudian menentukan tujuan dari proses tersebut khususnya dalam pembelajaran Fisika dengan memecah-mecahkan unsur-unsur pokok menjadi bagian-bagian kecil dan menentukan struktur yang keseluruhannya sehingga akan sampai pada proses menciptakan variasi jawaban yang baru dan unik.

\section{Kendala dan Cara Mengatasi Kendala Konseptual dalam Berpikir Kreatif} Menurut Munandar (2004) mengembangkan dan mewujudkan potensi kreatif seseorang, dapat mengalami berbagai hambatan, kendala, atau rintangan yang dapat merusak bahkan mematikan kreativitas. Adapun beberapa kendala konseptual dalam berpikir kreatif yang meliputi kendala eksternal yaitu muncul dari lingkungan tertentumisalnyakendala kultur dan lingkungan dekatdaninternal yaitu ditimbulkan oleh diri sendiri misal kendala perseptual, intelektual, emosional, kendala imajinasi dan kendala dalam ungkapan bahasa.

Pemecahan masalah (kendala) adalah suatu usaha untuk dapat keluar dari keadaan yang sulit yaitu halangan dan rintangan demi perolehan hasil yang baik. Lebih lanjut menurut Adams (dalam Munandar,2009) teknik untuk mengatasi kendala konseptual secara umum adalah sebagai berikut: menggunakan cara-cara pemikiran yang non-verbal, mempunyai sikap mempertanyakan (questioning) atau menyelidiki (inquistive),kelancaran dan kelenturan dalam berpikir, menggunakan teknik-teknik kreatif yaitu teknik sumbang saran, daftar periksa, synectics, pemecahan masalah secara kreatif dapat membantu memperoleh gagasan inovatif terhadap masalah yang mengganggu.

\section{Indikator Kemampuan Berpikir Kreatif}

Dalam penelitian ini kemampuan berpikir kreatif yang digunakan adalah kemampuan berpikir yang berhubungan dengan kognitif-intelektual yang merupakan indikator kemampuan berpikir kreatif untuk tes, dan yang 
berhubungan dengan afektif-perasaan digunakan sebagai indikator kemampuan berpikir kreatif untuk observasi.

Berdasarkan pendapat di atas maka dalam penelitian ini indikator yang akan digunakan hanya dibatasi pada kognitif dan afektif yaitu Kognitif-Intelektual (1) Kemampuan Berpikir Lancar (fluency)yaitu menjawab dengan sejumlah jawaban yaitu selalu memikirkan lebih dari satu jawaban.Arus pemikiran lancar yaitu lancar mengungkapkan gagasan-gagasannya (2) Kemampuan Berpikir Luwes (Flexibility) ditandai mampu mengubah cara atau pendekatan yaitu dapat melihat suatu masalah dari sudut pandang yang berbeda. Arah pemikiran yang berbedabeda yaitu dalam memecahkan situasi selalu mempunyai posisi yang berbeda dari siswa lainnya. (3) Berpikir Asli/Original yaitu memberikan penguraian atau jawaban yang tidak lazim, jawaban yang memiliki posisi lain dari yang lain yang jarang diberikan kebanyakan orang. (4) Berpikir Terperinci (elaboration) ditandai dengan mencoba atau menguji detil-detil untuk melihat arah yang akan ditempuh.Mempunyai rasa keindahan yang kuat sehingga tidak puas dengan penampilan yang kosong atau sederhana.Mengembangkan,

menambahkan atau memperkaya suatu gagasan. Menambah garis-garis, warnawarna, dan bagian-bagian terhadap gambarnya sendiri atau gambar orang lain.Afektif-Perasaan (1) Sikap rasa ingin tahu (2) Sikap Imajinatif (3) Sikap Merasa Tertantang Oleh Kemajemukan (4) Sikap Berani Mengambil Resiko dan (5) Sikap Menghargai. Masing-masing terbagi menjadi beberapa deskriptor.

\section{METODE PENELITIAN}

Penelitian ini dilakukan untuk menganalisis kemampuan berpikir kreatif siswa kelas VIII SMP Xaverius Kota Lubuklinggaudalam mempelajari materi Fisika yaitu cahaya dan pembentukan bayangan pada cermin dan lensa dan karena penelitian ini bersifat mengkaji atau menggambarkan keadaan atau kondisi secara apa adanya yang ada di lingkungan, maka penelitian ini menggunakan metode deskriptif kualitatif jenis studi kasus, yaitu strategi penelitian yang hanya fokus pada suatu kasus yang ingin peneliti selidiki secara cermat dengan memberi batasan pada kasus-kasus lain (Creswell, 2010).

\section{Subjek Penelitian}

Populasi dalam penelitian ini adalah seluruh siswa kelas VIII SMP Xaverius Kota Lubuklinggau tahun pelajaran 2015/2016. Sedangkan yang menjadi sampel dalam penelitian ini adalah salah satu kelas dari keseluruhan populasi yang dipilih secara purposive sampling, yaitu teknik penentuan sampel dengan pertimbangan tertentu. Sesuai dengan rekomendasi guru yang mengajar IPA di kelas VIII, maka dari lima kelas, dipilih kelas VIII-D dengan jumlah siswa sebanyak 28 orang yang menjadi sampel penelitian.

\section{Teknik dan Prosedur Pengumpulan Data}

Data yang dikumpulkan dalam penelitian ini diperoleh dengan cara triangulasi yaitu Observasi kognitif dilihat dari jawaban siswa dalam menjawab soal tes yang berjumlah tujuh butir soal berbentuk uraian untuk mengetahui tingkat kemampuan berpikir kreatif siswa yang disusun berdasarkan indikator kognitif-intelektal. Observasi Afektif yaitu untuk mengukur kemampuan berpikir kreatif siswa yang disusun berdasarkan indikator berpikir kreatif sebagai acuan penyusunan instrumen yang berjumlah 15 deskriptor yang harus di amati. Wawancara yaitu pengumpulan data dengan cara peneliti 
melakukan face to-face interview (wawancara berhadap-hadapan) dengan partisipan (Creswell, 2010).Maka dalam penelitian ini jenis wawancara yang digunakan adalah wawancara langsung antara peneliti dan peserta didik, dan merupakan wawancara terstruktur. Wawancara ini dilakukan untuk memperoleh data tentang penyebab kesulitan siswa dalam menyelesaikan soal-soal tes kemampuan berpikir kreatif, dengan menyiapkan sederetan pertanyaan lengkap dan terperinci yang sudah dipikirkan oleh peneliti yang berjumlah 20 butir pertanyaan.

\section{Prosedur Analisis Data}

Pengolahan data dalam penelitian ini dilakukan dengan menggunakan triangulasi.Adapun penjelasan mengenai analisis data dari ketiga instrumen dianalisis dengan cara sebagai berikut:

a. Analisis Data Hasil Observasi Kognitif-Intelektual

Teknik analisis data untuk hasil observasi jawaban siswa pada soal tes bentuk uraian pada aspek kognitifintelektual dilakukan dengan menggunakan pedoman penyekoran analitik. Menurut Ekawati dan Sumaryanta (2011) teknik penyekoran analitik digunakan pada tes uraianobjektif yang mana jawaban siswa diuraikan dengan urutan tertentu. Jika siswatelah menulis rumus yang benar, memasukkan angka ke dalam formuladengan benar, menghasilkan perhitungan yang benar, dankesimpulan yang benar diberikan skor. Jadi, skor suatu butir merupakanpenjumlahan dari sejumlah skor dari setiap respon pada soal tersebut.

b. Analisis Data Hasil Observasi Afektif

Teknik analisis data untuk hasil observasi menggunakan skala Penyekoran Holistik. Dengan memberikan tanda ceklis pada kolom nol, satu, atau dua untuk tiap-tiap deskriptor yang diamati. Menghitung nilai presentase kemampuan berpikir siswa masing-masing instrumen tersebut dihitung menggunakan rumus sebagai berikut:

$$
N P=\frac{R}{S M} x 100 \%
$$

(Purwanto, 2010:102)

Keterangan :

$\mathrm{NP}=$ nilai presentase kemampuan

berpikir kreatif

$\mathrm{R} \quad=$ skor mentah yang diperoleh siswa

$\mathrm{SM}=$ Skor maksimum observasi

kognitif/afektif yang

bersangkutan

Untuk menghitung tiap-tiap indikator dan rata-rata kemampuan berpikir kreatif siswa :

$\bar{x}=\frac{\sum x_{i}}{n}($ Sugiyono, 2012$)$

Keterangan:

$\bar{x} \quad=$ rata-rata kemampuan berpikir

kreatif siswa

$\sum \quad=$ psilon (baca jumlah)

$x_{i} \quad=$ nilai kemampuan berpikir

kreatif siswa ke i sampai ke $\mathrm{n}$

$n \quad=$ jumlah individu (banyaknya siswa)

Selanjutnya mengubah presentase menjadi nilai dengan kategori, maka dari data yang mula-mula berupa presentase, diubah kembali menjadi data kualitatif. Adapun acuan pengubahan presentase menjadi kategori kualitatifadalah sebagai berikut:

Tabel 1.Konversi Presentase Kemampuan Berpikir kreatif

\begin{tabular}{lcc}
\hline No & $\begin{array}{c}\text { Presentase yang } \\
\text { Diperoleh }\end{array}$ & Kategori \\
\hline 1. & $81 \%-100 \%$ & Sangat kreatif \\
2. & $61 \%-80 \%$ & Kreatif \\
3. & $41 \%-60 \%$ & Cukup kreatif
\end{tabular}




\begin{tabular}{ccc}
4. & $21 \%-40 \%$ & Kurang kreatif \\
5. & $0 \%-20 \%$ & tidak kreatif \\
\hline
\end{tabular}

(Sumber: modifikasi dari Ekawati danSumaryanta, 2011: 61)

\section{Pemeriksaan Keabsahan Data}

Untuk memeriksa keabsahan data pada penelitian menggunakan kredibilitas (credibility) atau derajat kepercayaan. kredibilitas adalah sebagai berikut, untuk memeriksa akurasi hasil penelitian, peneliti perlu digunakannya strategi-strategi validitas karena hal ini dapat meningkatkan kemampuan peneliti dalam menilai keakuratan hasil penelitian.

Kredibilitas

(credibility)

merupakan penetapan hasil penelitian kualitatif yang kredibel atau dapat dipercaya dari perspektif partisipan. Partisipan adalah orang yang dapat menilai secara sah kredibilitas hasil penelitian. Adapun strategi validitas yang digunakan dalam penelitian ini untuk meningkatkan kredibilitas adalah dengan triangulasi.

\section{Pertanggungjawaban Penelitian}

a. Validasi Soal Kemampuan Berpikir Kreatif

\section{1) Uji validasi}

Dalam penelitian ini 10 soal di uji cobakan ke siswa kelas VIII.A. Soal yang di berikan pada siswa tersebut sudah sesuai dengan indikator kemampuan berpikir kreatif. Soal yang dinyatakan valid sebanyak tujuh butir soal.

Teknikpengujiannya

menggunakan korelasi Produk Momen Pearsondan dikategorikan pada kriteria menurut (Arikunto, 2010:319),adapun rekapitulasi validasi butir soal tes hasil diperoleh dari 10 soal yang di uji cobakan di dapat tujuh soal yang dinyatakan valid dan reliabel.

2) Uji Reliabilitas
Uji reliabilitas ditujukan untuk mengetahui konsistensi tes, apakah tes yangdigunakan dapat diandalkan dan tetap konsisten jika pengukuran diulang. Uji raliabilitas yang dilakukan dengan metode KuderRichardson dengan perhitungan alpha (Arikunto, 2010: 239). Berdasarkan hasil perhitungan diperoleh $\mathrm{r}_{11}=0,82$, selanjutnya interpretasi nilai $\mathrm{r}_{\text {II dikategorikan berdasarkan pendapat }}$ Guilford (dalam Haris dan Jihad, 2010). Sehingga disimpulkan bahwa soal tersebut memiliki tingkat reliabilitas tinggi.

b. Validasi Instrumen Wawancara

Instrumen wawancara dalam penelitian ini dibuat sendiri oleh peneliti, yang berisi sederetan pertanyaan yang berkaitan dengan materi cahaya. Pedoman wawancara penelitian ini telah divalidasi secara konstruksi oleh dua dosen ahli dari STKIP-PGRI Lubuklinggau. Dalam penelitian ini adapun hasil penilaian kedua dosen tersebut diperoleh kesimpulan bahwa pedoman wawancara dapat dan layak digunakan dalam penelitian ini setelah proses perbaikan.

\section{c. Validasi Lembar Observasi Kemampuan Berpikir Kreatif}

Lembar observasi disusun berdasarkan indikator kemampuan berpikir kreatif pada aspek afektif yang akan diamati selama proses pembelajaran berlangsung. Pada penelitian ini lembarobservasi kemampuan berpikir kreatif telah divalidasi secara konstruksi sebelum digunakan dalam penelitian. Validasi ini dilakukan dua orang dosen ahli dari STKIP-PGRI Lubuklinggau. Setelah melalui beberapa proses perbaikan dengan kedua validator, maka didapatkan hasil penilaian dari kedua dosen ahli tersebut diperoleh kesimpulan bahwa lembar observasi afektif pada aspek afektif kreatif dapat 
dan sudah dianggap layak digunakan dalam penelitian ini.

\section{HASIL DAN PEMBAHASAN}

\section{Hasil Penelitian}

a. Analisis Data Kemampuan Berpikir Kreatif Siswa

1) Analisis Data Observasi Kognitif

Analisis data dilakukan dengan mencari rata-rata presentase masingmasing indikator kemampuan berpikir kreatif terlebih dahulu dan mengkategorikan berdasarkan hasil presentase. Hasil analisis rata-rata presentase masing-masing indikator kemampuan berpikir kreatif siswa dapat dilihat pada gambar 1 .

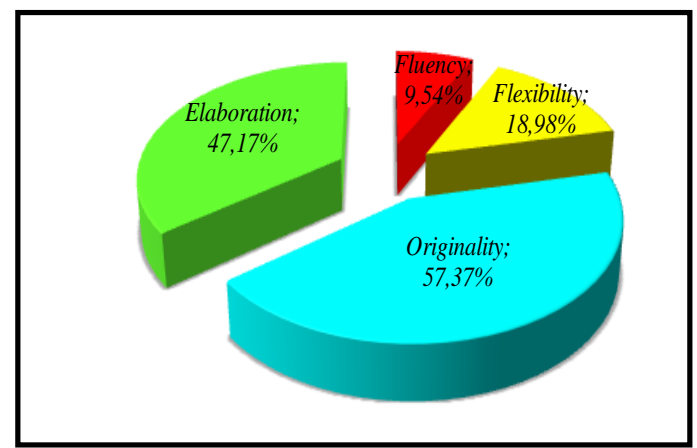

Gambar 1.Rata-Rata Presentase

IndikatorKemampuan Berpikir Kreatif

SiswaDitinjau dari Hasil Observasi Kognitif

Setelah menentukan rata-rata peresentase indikator kemampuan berpikir kreatif siswa, maka selanjutnya menentukan persentase kemampuan berpikir kreatif siswa secara keseluruhan siswa dan kategorinya. Adapun rata-rata persentase kemampuan berpikir kreatif siswa secara keseluruhan siswa dapat dilihat pada gambar 2 .

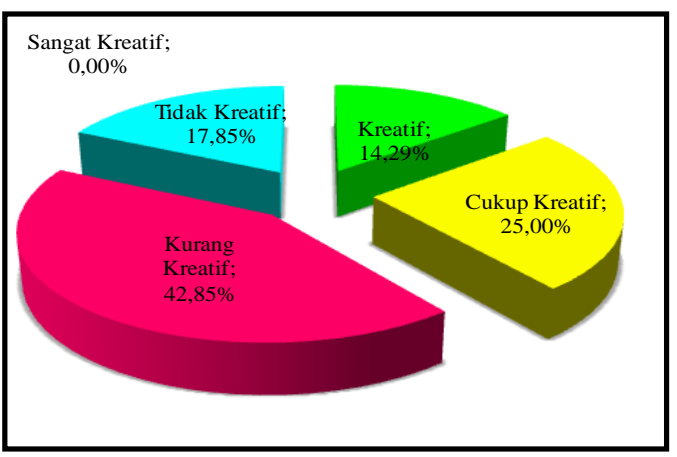

Gambar 2. Rata-Rata Persentase Kemampuan Berpikir Kreatif Siswa dari Seluruh Siswa

Berdasarkan hasil analisis data, siswa kreatif atau tidak dalam memberikan penyelesaian atau jawaban dari suatu soal dapat diketahui dengan melakukan perbandiingan antara skor yang dicapai siswa dalam menjawab soal dan skor maksimum yang mungkin dicapai siswa dari keseluruhan soal kemudian dipersentasekan, serta mengkategorikan hasil persentase siswa tersebut.

\section{2)Analisis Data Observasi Afektif}

Dari analisis rata-rata persentase masing-masing indikator kemampuan berpikir kreatif siswa dapat dilihat pada gambar 3.

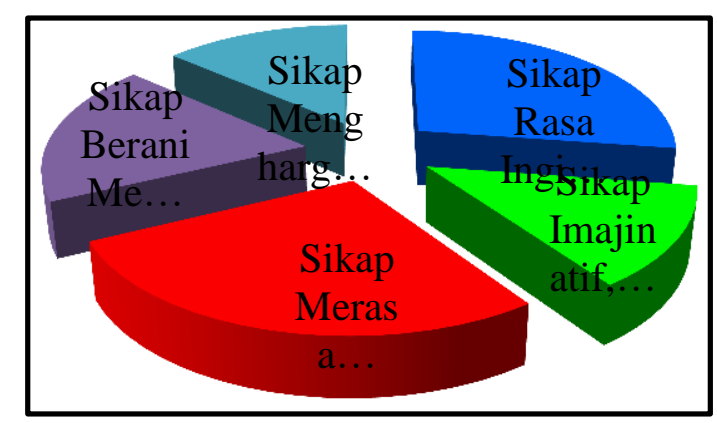

Gambar 3.Rata-Rata Persentase Indikator Kemampuan Berpikir Kreatif SiswaDitinjau dari Hasil Observasi Afektif Kemampuan Berpikir Kreatif

Rata-rata persentase kemampuan berpikir kreatif siswa keseluruhan dapat dilihat pada gambar 4 . 


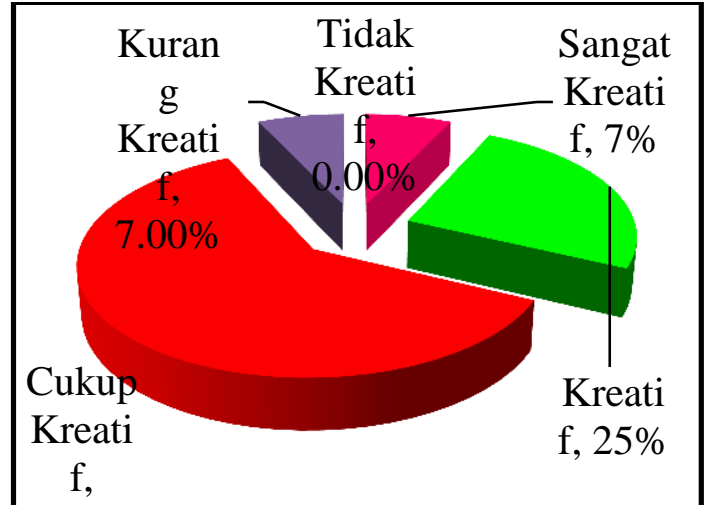

Gambar 4.Rata-Rata Persentase Kemampuan Berpikir Kreatif Siswadari Seluruh Siswa

Berdasarkan hasil analisis data, siswa kreatif atau tidak dalam proses pembelajaran yang berlangsung di kelas dapat diketahui dengan melakukan suatu perbandingan yaitu perbandingan antara skor aktivitas kemampuan berpikir kreatif siswa tersebut di kelas dan skor maksimum yang mungkin dicapai siswa dari keseluruhan proses observasi yang berlangsung di kelas. Kemudian dipersentasekan, serta menentukan hasil persentase tersebut kedalam kategori kemampuan berpikir kreatif siswa.

b. Kendala-kendala yang Dialami Siswa dalam Berpikir Kreatif dan Solusinya

Terdapat banyak cara yang dapat dilakukan untuk mengatasi kendala yang dialami siswa dalam berpikir kreatif pada bidang Fisika. Secara garis besar langkah yang digunakan untuk membantu mengatasi kendala tersebut menurut Wallas (dalam Luviandari Ayus, 2014) :

1) Mengivestigasi kesulitan yang dialami siswa

2) Mengalihkan perhatian dari hal-hal yang tidak penting

3) Mencari cara yang sesuai untuk mengatasi kesulitan tersebut (tahap iluminasi atauilumination).

4) Menilai atau menguji ketepatan cara penyelesaian yang digunakan pada tahap iluminasi.
Munandar (2004:231-233) akan dijelaskn pada tabel yang akan disajikan dibawah ini.

Tabel 3. Solusi untuk Mengatasi Kendala Berpikir Kreatif yang Dialami Siswa

\begin{tabular}{|c|c|c|}
\hline $\begin{array}{l}\text { Sebab } \\
\text { Utama }\end{array}$ & $\begin{array}{c}\text { Sebab } \\
\text { Khusus }\end{array}$ & Solusi Mengatasi \\
\hline \multirow{2}{*}{$\begin{array}{l}\text { Kendala } \\
\text { Eksternal }\end{array}$} & $\begin{array}{l}\text { Kendala } \\
\text { Kultural }\end{array}$ & $\begin{array}{l}\text { Mempertanyakan } \\
\text { atau menyelidiki } \\
\text { aspek-aspek yang } \\
\text { dibatasi atau } \\
\text { dianggap tidak } \\
\text { lazim. }\end{array}$ \\
\hline & $\begin{array}{l}\text { Kendala } \\
\text { Lingkugan } \\
\text { Dekat } \\
\text { (Fisik dan } \\
\text { Sosial) } \\
\end{array}$ & $\begin{array}{l}\text { Dihadapkan pada } \\
\text { kenyataan dan } \\
\text { rasionalitas yang } \\
\text { dapat terjadi } \\
\text { nantinya }\end{array}$ \\
\hline \multirow{5}{*}{$\begin{array}{l}\text { Kendala } \\
\text { Internal }\end{array}$} & $\begin{array}{l}\text { Kendala } \\
\text { Perseptual }\end{array}$ & $\begin{array}{l}\text { Menggunakan } \\
\text { cara pemikiran } \\
\text { yang non-verbal }\end{array}$ \\
\hline & $\begin{array}{l}\text { Kendala } \\
\text { Emosional }\end{array}$ & $\begin{array}{l}\text { Dilatih oleh guru } \\
\text { untuk dapat } \\
\text { mengkondisikan } \\
\text { diri sesuai situasi } \\
\text { yang terjadi } \\
\text { nantinya }\end{array}$ \\
\hline & $\begin{array}{l}\text { Kendala } \\
\text { Imajinasi }\end{array}$ & $\begin{array}{l}\text { Diberikan } \\
\text { kebebasan untuk } \\
\text { menciptakan daya } \\
\text { imajinasi yang } \\
\text { tetap berada pada } \\
\text { titik } \\
\text { keseimbangan. }\end{array}$ \\
\hline & $\begin{array}{l}\text { Kendala } \\
\text { Intelektual }\end{array}$ & $\begin{array}{l}\text { Menggunakan } \\
\text { teknik-teknik atau } \\
\text { strategi } \\
\text { pembelajaran } \\
\text { yang kreatif }\end{array}$ \\
\hline & $\begin{array}{l}\text { Kendala } \\
\text { dalam } \\
\text { Ungkapan }\end{array}$ & $\begin{array}{l}\text { Diajarkan sesuai } \\
\text { tingkat } \\
\text { kemampuan yang } \\
\text { dimiliki dalam } \\
\text { keterampilan } \\
\text { berbahasa } \\
\end{array}$ \\
\hline
\end{tabular}

solusi yang digunakan dalammengatasi kesulitan dalam berpikir kreatif oleh siswa sudah sesuai atau tidak dengan penyebab dan situasi siswa itu sendiri. Ini menjadi penting karena penilaian ini akan menjadi hasil akhir mengenai ketercapaian solusi dalam mengatasi suatu kesulitan yang dialami siswa. Jika 
tidak tepat atau malah menyimpang dari apa yang diharapkan maka perlu dilakukan perbaikan-perbaikan untuk merancang suatu solusi untuk mengatasi kesulitan ini yang benar-benar efektif dan tepat sasaran, dan jika terlalu menyimpang dapat dilakukan pengulangan pelaksanaan langkahlangkah yang sudah diuraikan di atas. Sehingga diperoleh solusi akhir yang efektif untuk mengatasi kesulitan dalam berpikir kreatif yang dialami oleh siswa.

\section{PEMBAHASAN}

Pada indikator Kemampuan Berpikir Lancar (Fluency)Pada setiap pertemuan guru berusaha mendorong siswa untuk mencetuskan banyak gagasan, jawaban, penyelesaian masalah, atau pertanyaan supaya kemampuan berpikir lancar yang dimiliki siswa dapat berkembang. Menurut Munandar (2004) prilaku siswa yang menunjukkan kemampuan berpikir lancar adalah siswa mengajukan banyak pertanyaan, menjawab dengan sejumlah jawaban, dan lancar mengungkapkan gagasangagasan.

Berdasarkan hasil observasi kognitif menunjukkan bahwa siswa pada butir soal nomor lima dan tujuh yang menggambarkan indikator kemampuan berpikir lancar hanya mencapai kategori tidak kreatif yaitu sebagian besar siswa kurang mampu dalam menyelesaikan soal uraian Fisika materi cahaya dan bahkan siswa tidak memberi jawaban pada kedua soal tersebut ternyata setelah dilakukan wawancara secara mendalam kepada subjek wawancara bahwa siswa mengalami kesulitan memahami konsep, kurang paham apa saja yang diketahui dalam soal sehingga siswa cenderung tidak menuliskan apa yang diketahui dari soal, siswa sulit untuk mengetahui apa yang ditanya dari soal, tidak dapat menentukan rumus yang tepat, kesulitan dalam memahami konsep sehingga siswa tidak mampu menghitung apa yang seharusnya menjadi jawaban pada soal, sulit dalam menerjemahkan soal, sehingga soal pada nomor lima dan tujuh yang menggambarkan indikator kemampuan berpikir lancar hanya dijawab dengan sekedarnya saja dan bahkan ada yang tidak menjawab sama sekali. Sehingga pada butir soal nomor lima dan tujuh hanya mencapai kategori tidak kreatif

Kemampuan Berpikir Luwes (Flexibility)Berdasarkan hasil observasi kognitif dilihat dari jawaban siswa menunjukkan bahwa siswa pada butir soal nomor satu, lima dan tujuh yang menggambarkan indikator kemampuan berpikir luwes hanya mencapai kategori tidak kreatif yaitu sebagian besar siswa tidak memberi jawaban pada soal nomor lima dan tujuh, yang diketahui pada soal nomor lima dan tujuh adalah jarak benda ke cermin, dan fokus cermin, serta yang ditanyakan pada soal adalah letak bayangan atau jarak bayangan dari cermin serta sifat-sifat bayangan yang terbentuk, berdasarkan jawaban siswa, terlihat siswa hanya menuliskan jawaban apa yang diketahui di dalam soal, tetapi siswa tidak mampu menuliskan apa yang ditanya dan tidak mampu menentukan rumus yang akan digunakan dalam menyelesaikan soal, tidak memberikan penafsiran yang berbeda dari siswa lain, siswa hanya memberikan satu cara penyelesaian masalah dalam soal.

Sehingga untuk butir soal ini siswa hanya mencapai kategori tidak kreatif. Selanjutnya untuk melihat kemampuan berpikir luwes siswa pada soal nomor satu, guru memberikan permasalahan dalam bentuk soal kemampuan berpikir kreatif yaitu disajikan permasalahan agar siswa mampu menjelaskan hukum pemantulan dan pembiasan cahaya pada peristiwa sehari-hari dengan sudut pandang yang lebih dari satu, kemudian setelah mengobservasi jawaban siswa, 
ternyata untuk soal nomor satu sudah cukup baik dilihat dari beberapa siswa yang mampu menjawab dengan lebih dari satu sudut pandang artinya siswa memiliki rencana yang baik untuk menyelesaikan soal, memiliki pemahaman dasar tentang soal yang ditanyakan sehingga siswa mampu mengembangkan konsep dasar dalam menyelesaikan soal nomor satu dengan indikator kemampuan berpikir luwes, hanya saja ada beberapa kalimat yang tidak baku digunakan dalam menjawab soal. Sehingga disimpulkan bahwa masih banyak aspek yang harus dikembangkan siswa dalam mencapai indikator ini.

Kemampuan Berpikir Original, kemampuan original adalah kemampuan untuk menyampaikan dan mengembangkan ide serta menguraikan ide tersebut dengan pengetahuan sendiri dan tidak terpikirkan oleh orang lain (Guilford, dalam Hidayati, 2010). Berdasarkan hasil observasi kognitif menunjukkan bahwa siswa pada butir soal nomor dua yang menggambarkan indikator kemampuan berpikir Original mencapai kategori cukup kreatif. Pada soal nomor dua disajikan permasalahan siswa diminta untuk membayangkan dan berimajinasi serta dapat menguraikan ide tersebut dengan pengetahuannya sendiri. Dilihat dari sebagian besar siswa sudah memberikan jawaban yang tidak lazim dan antara siswa satu dengan yang lain memiliki perbedaan pendapat atau gagasan dalam menyelesaikan soal nomor dua,Selanjutnya dijelaskan oleh

$$
\text { Munandar (2009) bahwa }
$$

keterampilan berpikir asli didefinisikan sebagai keterampilan dalam memberikan jawaban yang tidak lazim, yang lain dari yang lain, yang jarang diberikan kebanyakan orang. Hanya saja pada soal ini ada beberapa siswa yang menjawab dengan satu jawaban yang sudah lazim dijawab siswa lainnya dan tidak memberikan jawaban yang bervariasi. Sejalan pendapat Mustika (2013) bahwa
Semakin luas pengetahuan, semakin besar kemungkinan memunculkan ide baru yang berbeda atau tidak lazim digunakan kebanyakan orang, sehingga dapat mempengaruhi kemampuan berpikir asli seseorang. Sehingga dapat disimpulkan bahwa kemampuan siswa dalam mengembangkan indikator ini cukup baik tetapi ada aspek-aspek tertentu yang harus diperhatikan oleh siswa dalam mencapai indikator ini.

Kemampuan Berpikir Terperinci (Elaboration)adalah kemampuan untuk menguraikan segala sesuatu secara rinci.Pada soal nomor tiga guru menyajikan masalah siswa diminta untuk menjelaskan tentang pembiasan cahaya, soal nomor empat guru menyajikan gambar siswa diminta untuk melukiskan atau menggambarkan pembentukan bayangan pada cermin datar, pada soal nomor enam siswa diminta untuk menjelaskan pembentukan bayangan dan sifat-sifat bayangan pada lensa cembung.Berdasarkan hasil observasi kognitif dari jawaban siswa menunjukkan bahwa siswa pada butir soal nomor tiga, empat, dan enam yang menggambarkan indikator kemampuan berpikir terperinci mencapai kategori cukup kreatif.

Sebagian besar siswa sudah memberikan jawaban yang baik pada soal nomor tiga dan empat siswa dapat mengungkapkan gagasannya pada kedua soal tersebut dan bahasa yang digunakan untuk mengungkapkan gagasan dalam menjawab soal merupakan bahasa siswa sendiri bukan bahasa teks books, siswa mampu mengembangkan, menambahkan, dan memperkaya suatu gagasan dengan melakukan praktek sendiri untuk membuktikan pembiasan cahaya, dan sebagian siswa menggambarkan pembentukan bayangan pada cermin datar dengan menambahkan keterangan-keterangan pada gambar, warna-warna pada gambar, hal ini 
sejalan dengan pendapat yang diungkapkan

Munandar (2009) bahwa keterampilan memerinci adalah keterampilan dalam mengembangkan, menambahkan, memperkaya suatu gagasan, atau merinci detail-detail, serta memperluas suatu gagasan. Hanya saja ada beberapa siswa yng menjawab dengan satu jawaban yang sudah lazim dijawab siswa lainnya dan tidak memberikan jawaban yang bervariasi, dan pada soal nomor enam masih terdapat beberapa siswa yang tidak memberikan jawaban sama sekali, tidak semua siswa merasa mampu dalam memperhatikan detail-detail dari langkah kerja penyelesaian soal siswa bingung harus memulai darimana dalam memaparkan langkah-langkah kerja. Adapun soal ini menggunakan soal berbentuk cerita, yaitu untuk dapat melihat benda-benda yang kecil dengan menggunakan lup, siswa dimintauntuk dapat menguji detail-detail langkah yang akan ditempuh, dan dapat memperluas gagasan yang dimilikinya, sehingga pemahaman akan bahasa soal harus dimiliki oleh siswa. Hal ini juga dikuatkan oleh Wolfolk (dalam Mustika, 2013) bahwa pengetahuan (pemahaman bahasa) yang luas adalah dasar bagi kreativitas.

Kemungkinan hal ini disebabkan adanya kebiasaan mengandalkan teman satu kelompok ketika melakukan praktek, sehingga dengan keadaan seperti ini biasanya hanya siswa-siswa yang berminat dan serius dalam mengerjakan tugas-tugas praktek yang mengerti detail langkah kerja yang harus dilakukan dalam praktek tersebut. Sehingga untuk soal nomor enam ada yang hanya menyalin sebuah gambar dari soal saja tanpa memberi keterangandan jawaban apapun. Sehingga dapat disimpulkan bahwa kemampuan siswa dalam mengembangkan indikator inicukup baik tetapi ada aspek-aspek tertentu yang harus diperhatikan oleh siswa dalam mencapaiindikator ini.

Sikap Imajinatif, berdasarkan hasil pengamatan oleh observer, siswa sudah mampu melihat hal-hal dalam suatu gambar yang tidak dilihat oleh siswa lain, adapun siswa yang mendapatkan skor dua pada deskriptor ini berjumlah dua orang siswa, dan 17 orang siswa mendapat skor nol yaitu siswa tidak mampu melihat hal-hal dalam suatu gambar, memberikan contoh-contoh konsep yang berbeda dari yang dijelaskan oleh guru adapun siswa yang mendapatkan skor dua pada deskriptor ini berjumlah tiga orang siswa. Dan 11 orang siswa mendapat skor nol yaitu siswa tidak memberikan contoh konsep baik yang lazim diberikan oleh guru maupun konsep yang berbeda. Dan juga siswa sudah mampu mengetahui jika terjadi kekeliruan saat menjawab soal sebanyak tujuh orang siswa. Dan terdapat delapan orang siswa mendapatkan skor nol yaitu siswa tidak mengetahui kekeliruan suatu penyelesaian soal.Hal ini sesuai yang dikemukakan oleh Munandar (dalam Hidayati, 2010) bahwa definisi dari imajinatif adalah mampu memperagakan atau membayangkan hal-hal yang tidak atau belum pernah terjadi dan menggunakan khayalan tetapi mengetahui perbedaan antara khayalan dan kenyataan.

Sikap Merasa Tertantang oleh Masalah baru, siswa merasa tertantang oleh masalah baru dapat dilihat bahwa siswa merasa antusias untuk mengerjakan soal-soal yang berbeda dari yang biasa ditemuinya saat guru memberikan soal. Para siswa juga berusaha agar tugas yang dikerjakan baik dan tepat waktu meskipun ada beberapa siswa yang lalai mengerjakan tugasnya. Hal ini sesuai dengan yang dikemukakan oleh Munandar (dalam Hidayati, 2010) bahwa definisi dari merasa tertantang 
oleh masalah baru adalah terdorong untuk mengatasi masalah yang sulit, merasa tertantang olehsituasi-situasi yang rumit, dan lebih tertarik pada tugastugas yang sulit. Namun meskipun demikian, masih banyak siswa yang merasa biasa-biasa saja terhadap soal yang berbeda bahkan malas dan tidak menemukan solusi dari soal-soal tersebut.

Sikap Menghargai, pada proses pembelajaran yang diamati oleh observer terlihat bahwa siswa saling menghargai antara yang satu dengan yang lain, mereka menghargai pendapatnya dan menghargai pendapat orang lain ketika melakukan diskusi. Mereka menghargai kesempatan yang diberikan oleh guru baik saat diberi pertanyaan dan penyelesaian masalah namun masih ada beberapa siswa yang kurang memanfaatkan kesempatan itu dengan tidak melakukan aktivitas dan memberi respon terhadap kesempatan yang dimiliki dengan cara mengeluarkan ideidenya.

Padahal harusnya siswa merespon kesempatan yang diberikan, karena tiap tahapan atau langkah aktivitas siswa akan diamati dan mendapatkan skor, karena siswa tidak merespon maka siswa tidak mendapatkan skor atau skor yang diberikan adalah nol. Siswa menghargai kebebasan yang diberikan kepada mereka ketika berdiskusi dengan melakukan penyelesaian masalah dengan langkah yang tepat, namun masih ada siswa yang melakukan penyelesaian masalah dengan langkah yang kurang tepat, dan masih ada siswa yang tidak menghargai kebebasan yang diberikan oleh guru, hal ini ditandai dengan sedikitnya aktivitas siswa dalam menyelesaikan masalah saat diskusi dalam kelompoknya, siswa cenderung diam.

Kemampuan berpikir kreatif yang dicapai oleh siswa pada penelitian ini menunjukkan bahwa siswa masih mengalami kesulitan dalam mengembangkan kemampuannya, ini dapat dilhat dari hasil observasi kognitif dan wawancara tertutup yang dilakukan peneliti, siswa masih cenderung berpatokan pada satu jawaban yang mereka anggap benar saja yang mengartikan siswa terbiasa berpikir konvergen, siswa masih kesulitan menerjemahkan masalah yang dikemukakan dalam soal yang mengartikan soal yang digunakan guru sebagai alat ukur hanya mengacu pada penilaian kemampuan siswa dalam belajar dan kemajuan siswa selama menempuh program pembelajaran.

Dalam masalah fisika selain soal hitungan terdapat soal berbentuk cerita sehingga pemahaman bahasa sangat penting dalam menerjemahkan suatu kalimat dalam soal agar siswa dapat merencanakan dan mengambil keputusan langkah yang akan ditempuh dalam menyelesaikan soal, berdasarkan observasi dan wawancara masih banyak siswa yang tidak mampu menjawab soal hitungan dan bentuk cerita, tidak mampu menuliskan apa yang ditanya dalam soal, dan penggunaan rumus.

Untuk itu solusinya siswa harus lebih konsentrasi dalam membaca soal sehingga mampu menerjemahkan maksud soal karena pemahaman bahasa yang luas adalah dasar bagi kreativitas, guru membiasakan siswa untuk menjawab dan memberikan gagasan secara terbuka artinya tidak berpatok pada jawaban yang dianggap benar (streorotif).

Dari pemaparan diatas maka dapat disimpulkan secara garis besar penyebab ini dapat diatasi dengan cara sebagai berikut: mengintegrasikan kesulitan, menemukan penyebab kesulitan, berusaha mencari solusi yang digunakan untuk mengatasi kesulitan, berusaha mencari solusi yang digunakan untuk mengatasi kesulitan dan menilai atau merevisi solusi tersebut untuk 
menghasilkan solusi akhir yang efektif dan tepat.

Karena cara mengatasi atau menghindari kendala tentu bergantung dari jenis kendala itu, apakah kendalam eksternal atau kendala internal, apakah merupakan kendala intelektual, emosi, atau persepsil. Sehingga solusi yang ditawarkan benar-benar menjadi solusi yang dapat membantu individu/siswa untuk keluar dari zona kesulitannya dalam memecahkan masalah-masalah Fisika.

\section{SIMPULAN}

Berdasarkan tujuan penelitian dan analisis data tentang kemampuan berpikir kreatif pada materi cahaya siswa kelas VIII SMP Xaverius Kota Lubuklinggau yang telah dilakukan, maka dapat disimpulkan:

1. Dari hasil observasi kognitif secara keseluruhan yang mencakup empat indikator kemampuan berpikir kreatif dimana siswa mencapai kategori Kurang Kreatif, yaitu pada indikator kemampuan berpikir lancar sebanyak 9,54\% (kategori tidak kreatif), indikator kemampuan berpikir luwes sbanyak 18,98\% (kategori tidak kreatif), indikator kemampuan berpikir original sebanyak $57,37 \%$ (kategori cukup kreatif), indikator berpikir terperinci sebanyak $47,17 \%$ (cukup kreatif). Dari hasil observasi afektif secara keseluruhan yang mencakup 5 indikator kemampuan berpikir kreatif dimana siswa telah mencapai kategori cukup kreatif , yaitu indikator sikap rasa ingin tahu sebesar 75,45\% (kategori kreatif), sikap imajinatif sebesar $35,71 \%$ (kategori kurang kreatif), sikap merasa tertantang oleh masalah baru sebesar 76,19\% (kategori kreatif) dan, sikap berani mengambil resiko sebesar 51,19\% (kategori cukup kreatif), dan sikap menghargai sebesar $37,50 \%$ (kategori kurang kreatif).
Observasi kognitif yang dilengkapi dengan wawancara tertutup dan observasi afektif digunakan untuk mengidentifikasikan siswa yang memiliki kemampuan bepikir kreatif dengan kategori sangat kreatif, kreatif, kurang kreatif, dan tidak kreatif, dari hasil observasi kognitif yang diperoleh, empat orang siswa (kategori kreatif), tujuh orang siswa (kategori cukup kreatif), 12 orang siswa (kategori kurang kreatif), dan lima orang siswa (kategori tidak kreatif). Adapun hasil observasi afektif yang diamati selama proses pembelajaran berlangsung, dua orang siswa (kategori sangat kreatif), tujuh orang siswa (kategori kreatif), 17 orang siswa (kategori cukup kreatif), dan dua orang siswa (kategori kurang kreatif), dan tidak ada siswa yang tergolong kategori tidak kreatif.

2. Kendala yang dialami oleh siswa dalam mencapai indikator kemampuan berpikir kreatif berdasarkan hasil observasi kognitif dan afektif adalah kendala siswa mengisolasi masalah yang terdapat dalam suatu soal dari sudut pandangnya, mengemukakan gagasannya secara tertulis dan beberapa siswa cenderung malas membaca buku relevan selain buku yang diwajibkan dari yayasan Xaverius, siswa cenderung kesulitan dalam menerjemahkan gambar dan kata-kata menjadi bentuk rumusan matematis, ketidakmampuan siswa dalam melihat masalah atau soal dari berbagai sudut pandang yang berbeda, serta kendala dalam ungkapan sehingga siswa sulit untuk menggunkan bahasa yang tepat dalam mengemukakan gagasan.

3. Kendala yang dialami siswa dalam mengembangkan kemampuan berpikir kreatif dapat diatasi dengan solusi melakukan empat cara yaitu: mengintegrasikan kesulitan, 
menemukan penyebab kesulitan yang dialami siswa tersebut, kemudian berusaha mencari solusi yang dapat digunakan untuk mengatasi kesulitan, dan menilai serta merevisi solusi tersebut untuk menghasilkan solusi akhir yang efektif dan tepat.

\section{DAFTAR PUSTAKA}

Arikunto, Suharsimi. (2010). Prosedur Penelitian Suatu Pendekatan Praktik. Jakarta: PT. Rineka Cipta.

Budiono. (2005). Kamus Lengkap Bahasa Indonesia. Surabaya: Karya Agung.

Creswell, J.W. (2009). Research Design Pendekatan Kualitatif, Kuantitatif, dan Mixed. (A. Fawaid, Terjemahan). Yogyakarta: Pustaka Pelajar.

Ekawati, Estina dan Sumaryanta. (2011). Pengembangan Instrumen Penlaian Pembelajaran Matematika SD/SMP. Yogyakarta: Kementerian Pendidikan Nasional Badan Pengmbangan Sumber Daya Manusia Pndidikan dan Penjaminan Mutu Pendidikan Pusat Pengembangan dan Pemberdayaan Pendidik dan Tenaga Kependidikan (PPPPTK) Matematika

Haris dan Jihad. (2010). Evaluasi Pembelajaran. Yogyakarta: Multi Pressindo.

Hidayati, Faridah. (2010). Peningkatan Kreativitas Siswa pada Pembelajaran Matematika dengan Pokok Bahasan Bangun Ruang Sisi Datar (BRSD) di Kelas VIII SMP N 1 Tegalrejo. Skripsi tidak diterbitkan. Yogyakarta: Jurusan FMIPA universitas Negeri Yogyakarta.

Kompri. (2015). Manajemen Pendidikan Komponen-komponen Elementer Kemajuan Sekolah. Yogyakarta: Ar-Ruzz Media.

Munandar, Utami. (2009). Pengembangan Kreativitas Anak Berbakat. Jakarta: PT. Rineka Cipta. 
Mustika, (2013). Analisis Kemampuan Berpikir Kreatif Siswa SMP dalam Pembelajaran Pendidikan Teknologi Dasar (PTD). Jurnal Pengajaran MIPA. 18(1), 60-88.

Purwanto, Ngalim. (2010). Prinsipprinsip dan Teknik Evaluasi Pengajaran. Bandung: Remaja Rosdakarya

Slameto. (2010). Belajar dan Faktorfaktor yang Mempengaruhinya. Jakarta: PT. Rineka Cipta.

Sudarma, Momon. (2013). Mengembangkan Keterampilan Berpikir Kreatif. Jakarta: Rajawali Pers.

Sugiyono. (2008). Memahami Penelitian Kualitatif. Bandung: CV. Alfabeta.

(2012). Statistka untuk Penelitian. Bandung: CV. Alfabeta. 